\title{
Ramularia leaf spot severity and effects on cotton leaf area and yield ${ }^{1}$
}

\author{
João Paulo Ascari², Inês Roeder Nogueira Mendes², \\ Vanessa Costa da Silva², Dejânia Vieira de Araújo ${ }^{2}$
}

\section{ABSTRACT}

Cotton monoculture favors the development of diseases such as ramularia leaf spot, which causes early defoliation and boll rotting, thus decreasing yield. This study aimed at evaluating the severity of ramularia leaf spot and its effects on cotton leaf area and yield. The experiment was conducted in a triple $(4 \times 3 \times 2)$ factorial design, consisting of four cultivars (FM940GLT, FM944GL, TMG42WS and TMG43WS), three thirds of the plant (lower, middle and upper) and two management conditions (with and without fungicide application). To the variable area under the disease progress curve, the lowest values were observed in the upper third of the TMG42WS and TMG43WS cultivars, with the lower and middle thirds presenting the highest severity. The condition managed with fungicide and the upper third showed the lowest values for area under the disease progress curve. The leaf area was negatively affected by the ramularia leaf spot. Concerning the seed and fiber yields, the highest averages were observed for the middle third and the condition managed with fungicide. There was no statistical difference for cotton yield loss.

KEYWORDS: Gossypium hirsutum L.; Ramularia areola; disease progress curve.

\section{INTRODUCTION}

Cotton (Gossypium hirsutum L.) crops are very important for the Brazilian agribusiness. The average national production reached 3,531.0 thousand $\mathrm{Mg}$ of seeds in 2015/2016, in a cultivated area of 958.5 thousand hectares. The Mato Grosso State accounts for about $65.8 \%$ of the national production, with average yield of 3,886 kg ha-1 of seeds (Conab 2016).

Large areas of cotton monoculture combined with inadequate phytosanitary management have caused the occurrence of some diseases at early plant stages. Ramularia leaf spot, caused by the Ramularia

\section{RESUMO}

Severidade e efeitos da mancha de ramulária na área foliar e produtividade de algodoeiro

O monocultivo de algodão favorece o desenvolvimento de doenças como a mancha de ramulária, que provoca a desfolha precoce e o apodrecimento das maçãs, reduzindo a produtividade. Objetivouse avaliar a severidade da mancha de ramulária e seus efeitos sobre $\mathrm{a}$ área foliar e a produtividade de algodoeiro. $\mathrm{O}$ delineamento experimental foi constituído em fatorial triplo $(4 \times 3 \times 2)$, sendo quatro cultivares (FM940GLT, FM944GL, TMG42WS e TMG43WS), três terços da planta (inferior, médio e superior) e duas condições (tratadas e não tratadas com fungicida). Para a variável área abaixo da curva de progresso da doença, os menores valores foram verificados no terço superior das cultivares TMG42WS e TMG43WS, sendo o inferior e o médio os mais severos. A condição tratada com fungicida e o terço superior apresentaram os menores valores de área abaixo da curva de progresso da doença. A área foliar foi afetada negativamente pela mancha de ramulária. Com relação à produtividade em caroço e pluma, foram observadas as maiores médias para produtividade no terço médio e na condição tratada com fungicida. Não houve diferença estatística para dano à produtividade do algodoeiro.

PALAVRAS-CHAVE: Gossypium hirsutum L.; Ramularia areola; curva de progresso de doença.

areola (Speg.) Cif. fungus, is one of the main fungal diseases in cotton crops (Aquino et al. 2008a, Novaes et al. 2011).

The cotton fiber yield losses caused by this disease reached $36.8 \%$ in the region of Tangará da Serra, Mato Grosso State, Brazil (Gilio 2014), and $68.7 \%$ in India (Shlvankar \& Wangikar 1992). These yield losses are due to the field conditions, which favor the fungus by the microclimate formed under the plant canopy, with high humidity and mild temperatures $\left( \pm 24^{\circ} \mathrm{C}\right)$. These characteristics form a gradient of severity in the plant, with leaves in the lower third being more affected by the disease, which

1. Manuscript received in Aug./2016 and accepted for publication in Dec./2016 (http://dx.doi.org/10.1590/1983-40632016v4642781).

2. Universidade do Estado de Mato Grosso, Centro de Pesquisas, Estudos e Desenvolvimento Agroambiental, Laboratório de Fitopatologia, Tangará da Serra, MS, Brazil.E-mails: joaoascari321@gmail.com, ynes_nogueira@hotmail.com, vanessacosta.bbu@hotmail.com,dejania@unemat.br. 
progresses to the middle and upper thirds of the plant (Aquino et al. 2008b, Curvelo et al. 2010).

In contact with cotton leaves, especially in the abaxial side, $R$. areola conidia take about $12 \mathrm{~h}$ to emit germinative tubes, and cause apparent symptoms between 12 and 22 days after inoculation. Sporulation occurs through the leaf stomata, including stomata present in the leaf veins, thus indicating a possible colonization of xylem vessels, favoring the transport of pathogenic structures to the plant tissues, increasing the disease aggressiveness (Curvelo et al. 2010).

The inoculum pressure of $R$. areola may accelerate foliar abscission and cause total loss of the lower third of the plant. When the disease symptoms appear early in the crop cycle, the severity progression causes capsule decay, premature boll opening and decreased yield in the thirds more affected, as well as decreased fiber quality (Suassuna \& Coutinho 2014).

The first symptoms of the disease are observed in the lower third of the plant, spreading to the middle and upper thirds according to the phenological development of the plants. Therefore, evaluations must be carried out separately for each third of the plant, in order to detect the disease at the beginning of the infection process and assist in the decision making on chemical control, consequently minimizing losses to the plant leaf and yield (Pizzato et al. 2013, Gilio 2014).

The chemical control with fungicides, combined with the genetic control by using resistant cultivars, is among the most efficient measures to manage cotton diseases (Gonçalves et al. 2010). Fungicide applications usually start soon after the first symptoms of the disease are confirmed by plant monitoring, which is needed since most of the cultivars used in the Mato Grosso State are susceptible to diseases (Mehta \& Menten 2006).

In this context, this study aimed at evaluating the severity of ramularia leaf spot and its effects on cotton leaf area and yield.

\section{MATERIAL AND METHODS}

The experiment was conducted at the Universidade do Estado de Mato Grosso (14³9'53'S and $\left.57^{\circ} 25^{\prime} 46^{\prime \prime} \mathrm{W}\right)$, in Tangará da Serra, Mato Grosso State, Brazil, in 2015.

A randomized blocks design, in a $4 \times 3 \times 2$ factorial arrangement, was used, consisting of four early-mid maturity cultivars (FM940GLT - average height and flat leaf; FM944GL - high height and flat leaf; TMG42WS and TMG43WS - mean height and flat leaf), three thirds of the plant (lower, middle and upper) and two management systems (with and without fungicide application), with four replications. The three thirds of the plants were divided considering the number of nodes in each third, according to Aquino et al. (2008b) (lower third as the 1 st to the 7 th node, middle as the 8 th to the 14 th node and upper as above the 15 th node of the main branch). The leaf area was assessed using a $4 \times 2$ factorial arrangement, consisting of the four cultivars and two managements, with four replications.

The plots consisted of $5.0 \mathrm{~m}$-long and $3.80 \mathrm{~m}$-wide areas, with plant rows spaced $0.76 \mathrm{~m}$ apart. The area evaluated comprised the two central rows, discarding $0.5 \mathrm{~m}$ from each end, due to border effect.

The seed treatment was performed on the same day of sowing, using a carboxin + thiram-based product, at a rate of $0.8 \mathrm{~L} 100 \mathrm{~kg}^{-1}$ of seeds. Seeds were sowed manually on January 15 (2015), to a final density of 8 plants $\mathrm{m}^{-1}$. Weeds were controlled manually and insect pests with insecticides registered for the crop. Growth regulator was applied at 50, 75 and 100 days after sowing, using mepiquat chloride $\left(25 \mathrm{~g} \mathrm{ha}^{-1}\right)$.

Fungicides were applied (in treatments managed with chemical control) from 77 days after sowing, shortly after the first symptoms of ramularia leaf spot appeared on older leaves, in the lower third of the plants. Fungicides were applied at intervals of 7 days, rotating the active ingredients trifloxystrobin $\left(60 \mathrm{~g} \mathrm{ha}^{-1}\right)+$ prothioconazole $\left(70 \mathrm{~g} \mathrm{ha}^{-1}\right)$, pyraclostrobin $\left(100 \mathrm{~g} \mathrm{ha}^{-1}\right)$, difoconazole $\left(75 \mathrm{~g} \mathrm{ha}^{-1}\right)$ and azoxystrobin $\left(90 \mathrm{~g} \mathrm{ha}^{-1}\right)+$ benzovindiflupir $\left(45 \mathrm{~g} \mathrm{ha}^{-1}\right)$.

The ramularia leaf spot disease was identified and its severity was evaluated at intervals of 14 days, in six plants of the evaluation area, using the diagrammatic scale developed by Aquino et al. (2008a). The disease severity was evaluated with separated scores for each third, considering the lower, middle and upper thirds (Aquino et al. 2008b). The ramularia leaf spot severity scores were used to calculate the disease progress curve (Bergamin Filho 2011).

The area under the disease progress curve was determined using the following equation (Campbell \& Madden 1990): 


$$
\text { AUDPC }=\sum_{\mathrm{i}=1}^{\mathrm{n}-1}\left\{\left[\frac{\left(\mathrm{y}_{\mathrm{i}}+\mathrm{y}_{\mathrm{i}+1}\right)}{2}\right] *\left(\mathrm{t}_{\mathrm{i}+1}-\mathrm{t}_{\mathrm{i}}\right)\right\}
$$

in which $n_{i}$ is the number of evaluations, $y_{i}$ the ramularia leaf spot severity in the $i$-th evaluation and $t_{i+1}-t_{i}$ the interval among evaluations (days).

The leaf area was evaluated at 57 and 134 days after sowing, randomly in two plants of the evaluation area. The length of the main vein of each leaf was measured using a ruler $(\mathrm{cm})$ and the average length was calculated using the equation described by Grimes \& Carter (1969): $A=0.4322 x^{2.3002}$, in which $A$ is the leaf area and $x$ the length of the main vein of the cotton leaf.

The cotton was manually harvested in each third of the plant and taken to the laboratory for weighing $(\mathrm{kg})$, being extrapolated to $\mathrm{kg} \mathrm{ha}^{-1}$ of cotton seeds. The fiber yield (\%) was calculated by the ratio of fiber (obtained after ginning) and cotton seed.

The cotton yield loss caused by the ramularia leaf spot was calculated according to the following equation (Nkalubo et al. 2007):

$$
\text { loss } \%(\text { plot }) \mathrm{ij}=\frac{(\mathrm{PSi}-\mathrm{PDi}) * 100}{\mathrm{PSi}}
$$

in which loss \% (plot)ij is the loss percentage of the plot that received the cultivar $i$ in the replication $j$, $P S i$ the production of the cultivar $i$ in the plot without the disease and $P D i$ the production of the cultivar $i$ in the plot with the disease.

The data were subjected to analysis of variance by the F test and their means were compared by the ScottKnott test at $5 \%$, using the Sisvar statistical software. The averages were adjusted by the equation $\sqrt{\mathrm{x}+0.5}$.

\section{RESULTS AND DISCUSSION}

The triple interaction presented no significant effects, however, double interactions showed significant results. The treatments presented different areas under the disease progress curve of the ramularia leaf spot, with significant interactions between cultivar and third of the plant and between management and third of the plant, however, with no interactions between the cultivar and management. The cotton seed yield, fiber percentage and leaf area of the treatments were different, when considering the factors individually, and the yield losses were statistically similar.

The area under the disease progress curve values varied in the thirds of the plants. In the lower third, the TMG42WS cultivar presented the lowest value, while the highest values were found in the FM940GLT and FM944GL cultivars. The severity values of the middle and upper thirds of the plants increased with the progress of the disease in the area, especially in the lower third of the plants, with the TMG42WS and TMG43WS cultivars maintaining low ramularia leaf spot severity (Table 1).

The greatest area under the disease progress curve was found in the lower third of the plants. Ascari et al. (2016) also found a greater severity of this disease in the lower third of the plants, in two sowing seasons. These results were due to the microclimate formed in the lower third of the plants, which presented favorable temperature and humidity for the development and reproduction of the $R$. areola fungus (Rathaiah 1977).

The area under the disease progress curve results of the thirds of the plants differed from the ones by Pizzato et al. (2013 and 2014), who found higher values in the middle third of the plants, attributing this result to the evaluation method adopted, in which the disease symptoms were not quantified in the lower third of the plant, due to the loss of leaves.

The criterion used in the present study was to attribute a maximum severity score to a given sample

Table 1. Area under the disease progress curve (AUDPC) of ramularia leaf spot in the thirds of the plant of cotton cultivars.

\begin{tabular}{lrrrr}
\hline \multirow{3}{*}{ Thirds of the plant } & \multicolumn{4}{c}{ Cotton cultivar } \\
\cline { 2 - 4 } & TMG42WS & TMG43WS & FM940GLT & FM944GL \\
\cline { 2 - 4 } & & & & \\
\hline Lower & $355.44 \mathrm{Ac}$ & $519.94 \mathrm{Ab}$ & $938.46 \mathrm{Aa}$ & $804.22 \mathrm{Aa}$ \\
Middle & $177.59 \mathrm{Bb}$ & $197.45 \mathrm{Bb}$ & $386.86 \mathrm{Ba}$ & $336.98 \mathrm{Ba}$ \\
Upper & $64.22 \mathrm{Cb}$ & $87.76 \mathrm{Cb}$ & $136.04 \mathrm{Ca}$ & $125.11 \mathrm{Ca}$ \\
\hline CV $(\%)$ & & & \\
\end{tabular}

* Averages followed by different uppercase letters in the column and lowercase letters in the row differ statistically by the Scott-Knott test ( $\mathrm{p} \leq 0.05)$. Original data were transformed to $\sqrt{\mathrm{x}+0.5}$ 
when the plant leaf was lost, which was also used by Ascari et al. (2016). Beltrão et al. (2011) reported that a plant under stress directs energy and reorganizes its metabolism to combat the pathogen causing the injury, including the abortion of affected parts.

Based on the area under the disease progress curve found, the TMG42WS cultivar was less affected by the $R$. areola fungus, proving to be less susceptible to the ramularia leaf spot in the region of Tangará da Serra. The performance of this cultivar, regarding this disease, was similar to that observed by Cia et al. (2013 and 2015), for the FMT705 cultivar, which was considered resistant to ramularia leaf spot in the Mato Grosso State.

The FM940GLT and FM944GL cultivars were more susceptible to the ramularia leaf spot, as shown by their higher area under the disease progress curve values in the three thirds of the plant. However, the cultivars showed different results depending on the region. Cia et al. (2015) evaluated cotton cultivars in the São Paulo State and reported the FM940GLT cultivar as moderately resistant, denoting the importance of regional studies.

The different severity stages found in the cultivars are related to the different levels of resistance of each genotype to the genetic variation of the $R$. areola fungus (Cia et al. 2011, Fuzatto et al. 2011 and 2013, Girotto et al. 2013, Pezenti et al. 2013) and to the phenotypic instability of the cultivars (Cia et al. 2015). According to Johnson et al. (2013) and Ascari et al. (2016), the climate also affects the plant-pathogen interaction, as confirmed by the weather conditions recorded in the present study (Figure 1).
In the evaluation period prior to April 29 (2015), when precipitations were recorded more frequently, the disease progress curve was lower, with increasing severity from this date, due to the favorable temperatures and relative humidity to the fungal infectious process (Figure 2), which are, according to Rathaiah (1977), temperatures of $12-32{ }^{\circ} \mathrm{C}$, relative humidity of $80 \%$ and alternating periods of leaf wetting (wet at night and dry during the day).

The plants managed with fungicide applications after May 29 (2015) had a reduction in the disease progress curve, due to the low relative humidity and high temperatures. This result, according to Oliveira et al. (2010), is due to the tendency of the stomata of the plants under fungicide application to stay closed longer, thus reducing the penetration of the germinative tube emitted by the conidia of the $R$. areola fungus via stomata (Rathaiah 1977, Curvelo et al. 2010). Similar results were found by Johnson et al. (2013), in India, with low precipitation index reducing the disease, and periods of high relative humidity increasing the ramularia leaf spot severity.

The interaction considering the third of the plant $x$ management system allowed to affirm that the fungicide management is still one of the main forms of controlling the ramularia leaf spot, since the plots without fungicide application presented the highest area under the disease progress curve, especially affecting the lower third of the plants (Table 2).

The area under the disease progress curve values found confirm those observed by Suassuna et al. (2006a), who reported a disease progression in the middle and upper thirds, with increasing fungal infection in the lower third of the plants.

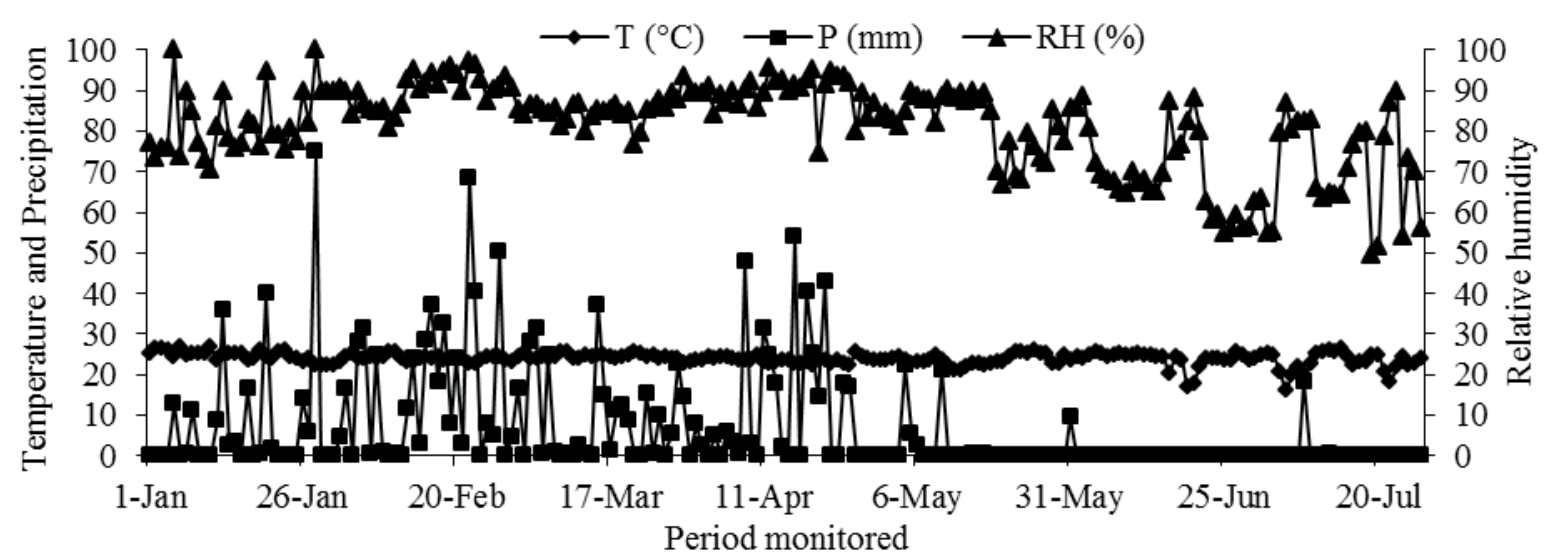

Figure 1. Average temperature $(\mathrm{T})$, precipitation $(\mathrm{P})$ and relative humidity $(\mathrm{RH})$ monitored during the study (Tangará da Serra, Mato Grosso State, Brazil, 2015). 
The area under the disease progress curve values found in the thirds of the plants managed with fungicide application differed from those observed by Pizzato et al. (2013), who used the FMT701 cultivar with fungicide application and found values for the area under the disease progress curve of $3,486.85$ (lower third), 4,229.25 (middle third) and 3,692.22 (upper third).

Variations in this disease severity in different crop seasons occur due to climatic differences, initial pathogen inoculum, degree of susceptibility of cultivars and spatial variation of the disease within the experimental plot (Cia et al. 2011, Fuzatto et al. 2013, Girotto et al. 2013, Pizzato et al. 2014).

The ramularia leaf spot affected the vegetative development of the cotton crop, decreasing the leaf area of the plants managed with fungicide application, however, the FM944GL cultivar (with and without fungicide application) presented a greater leaf area in both evaluations, even with a higher area under the disease progress curve (Table 3 ).

The high values for area under the disease progress curve found in plants managed without fungicide application negatively affected the vegetative and productive development of the cotton plants. Dias et al. (2015) also observed a great leaf loss and greater ramularia leaf spot severity in plants managed without fungicide application. Chitarra et al. (2005) recommend to start fungicide applications

Table 3. Leaf area of cotton cultivars with and without fungicide application.

\begin{tabular}{lcr}
\hline \multirow{2}{*}{ Cotton cultivar } & $\begin{array}{c}\text { Leaf area 1 } \\
(57 \text { DAS })\end{array}$ & $\begin{array}{r}\text { Leaf area 2 } \\
\text { (134 DAS) }\end{array}$ \\
\cline { 2 - 3 } & \multicolumn{2}{c}{$\mathrm{cm}^{2}$} \\
\hline FM940GLT & $1,438.57 \mathrm{~b}$ & $826.22 \mathrm{~b}$ \\
FM944GL & $2,133.48 \mathrm{a}$ & $1,356.34 \mathrm{a}$ \\
TMG42WS & $1,403.74 \mathrm{~b}$ & $792.44 \mathrm{~b}$ \\
TMG43WS & $1,531.31 \mathrm{~b}$ & $964.54 \mathrm{~b}$ \\
\hline Management system & & \\
With fungicide application & $1,924.23 \mathrm{a}$ & $1,496.88 \mathrm{a}$ \\
Without fungicide application & $1,329.32 \mathrm{~b}$ & $512.79 \mathrm{~b}$ \\
\hline CV (\%) & 14.57 & 19.22 \\
\hline
\end{tabular}

Averages followed by different lowercase letters in the column differ statistically by the Scott-Knott test $(p \leq 0.05)$. Original data were transformed to $\sqrt{x+0.5}$. $\mathrm{DAS}=$ days after sowing.

Table 2. Area under the disease progress curve (AUDPC) of the ramularia leaf spot in cotton cultivars (FM940GLT, FM944GL, TMG42WS and TMG43WS), depending on fungicide applications and thirds of the plant.

\begin{tabular}{lccr}
\hline \multirow{3}{*}{ Management system } & \multicolumn{3}{c}{ Thirds of the plant } \\
\cline { 2 - 4 } & \multicolumn{1}{c}{ Lower } & Middle & Upper \\
\cline { 2 - 4 } & & AUDPC & $61.12 \mathrm{Bc}$ \\
With fungicide application & $480.14 \mathrm{Ba}$ & $178.45 \mathrm{Bb}$ & $145.45 \mathrm{Ac}$ \\
Without fungicide application & $828.89 \mathrm{Aa}$ & $371.00 \mathrm{Ab}$ & 17.86 \\
\hline $\mathrm{CV}(\%)$ & & & \\
\hline
\end{tabular}

Averages followed by different uppercase letters in the column and lowercase letters in the row differ statistically by the Scott-Knott test ( $\mathrm{p} \leq 0.05)$. Original data were transformed to $\sqrt{\mathrm{x}+0.5}$.

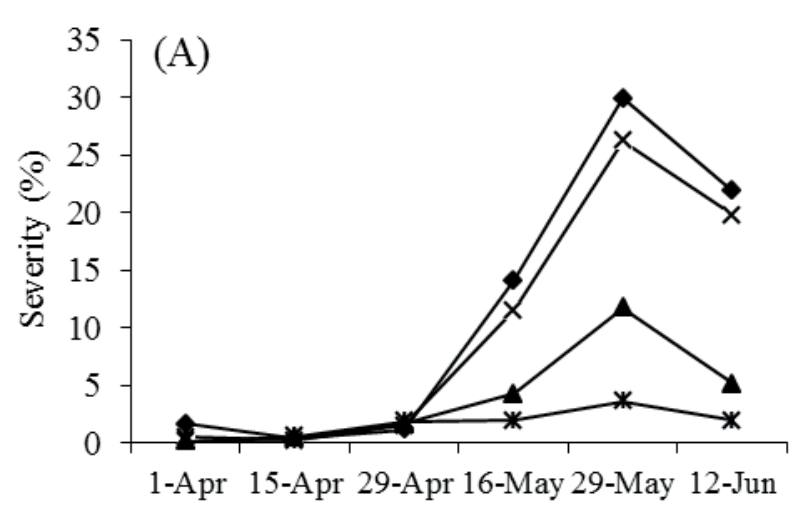

Date of disease evaluation

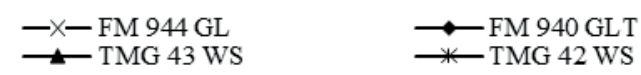

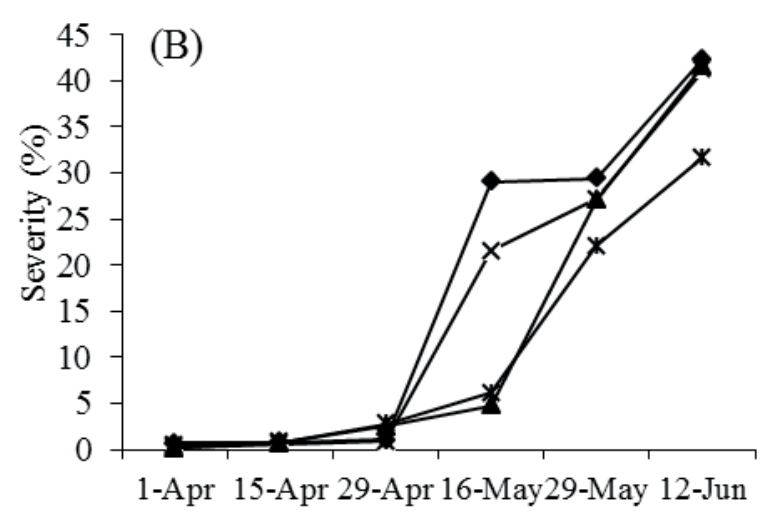

Date of disease evaluation
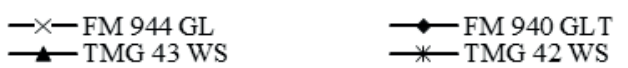

Figure 2. Disease progress curve of the ramularia leaf spot in cotton cultivars with (A) and without (B) fungicide application. 
when the disease affects $25 \%$ of leaf area in the lower third of the plant, to avoid production losses.

The TMG42WS, TMG43WS and FM940GLT cultivars had the least affected leaf area and were the least affected by the ramularia leaf spot, except for FM940GLT. Different results were found by Freitas et al. (2015), with a greater leaf area for these same cultivars, and by Dias et al. (2015), with a negative correlation between increased severity and leaf loss, in a densified cotton crop. However, the intrinsic climatic conditions of each region must be considered. According to Juliatti \& Polizel (2003), the yield loss caused by defoliation may reach $24 \%$.

Reductions of leaf area were found in the second evaluation, which was probably intensified by the infectious process of $R$. areola and the greater leaf loss in the lower third of plants managed without fungicide application. According to Suassuna \& Coutinho (2014), ramularia leaf spot with high severity may cause the total defoliation of the plant, hindering the formation of bolls and rotting of capsules, decreasing the cotton yield. According to Beltrão et al. (2011), foliar abscission occurs due to plant defense mechanisms against phytopathogenic fungi.

The FM940GLT cultivar had the lowest cotton seed yield, however, it presented the highest fiber yield. The plants managed with fungicide application were more productive than those without fungicide application. The middle third of the plants was the most productive one, however, it was not statistically different from the upper and lower thirds. The FM944GL, TMG42WS and TMG43WS cultivars had the highest cotton yields (Table 4).
The results found for the TMG42WS and TMG43WS cultivars showed a correlation between yield and area under the disease progress curve, since these cultivars had lower values for severity and higher yield, even with low leaf area. The effect of the disease was also observed in the thirds of the plant, with the lower third showing a higher area under the disease progress curve and lower yield. These results were due to the higher severity of the disease and better development of the fungus, favored by the microclimate in this third (Aquino et al. 2008b, Pizzato et al. 2013).

According to Beltrão et al. (2011), these cultivar responses to the injuries caused by the pathogenic fungi are due to the fact that the plant redirects its energy to combat the agent responsible for the injuries, thus decreasing its yield. Suassuna et al. (2006b) stated that the plant spends energy with defense mechanisms and decreases the accumulation of photoassimilates in the productive structures.

The fiber characteristics are, in general, better when the plant is less attacked by diseases (Beltrão et al. 2011), however, this was not confirmed in the present study, since the FM940GLT cultivar was very susceptible to the $R$. areola fungus and had the lowest cotton seed yield, but also the highest fiber yield. On the other hand, the FM944GL cultivar had the highest area under the disease progress curve and the highest cotton seed yield, but low fiber yield.

These results evidenced the effect of the genetic characteristics of the cultivars evaluated, such as the defense mechanisms that confer greater resistance to the attack of the pathogen (Suassuna \&

Table 4. Cotton seed yield, cotton fiber yield and fiber yield (\%), depending on cultivars, thirds of the plant and fungicide application management.

\begin{tabular}{|c|c|c|c|}
\hline \multirow{2}{*}{ Cotton cultivar } & Cotton seed yield & Cotton fiber yield & \multirow{2}{*}{$\begin{array}{c}\text { Fiber yield } \\
\%\end{array}$} \\
\hline & & & \\
\hline FM940GLT & $568.01 \mathrm{~b}$ & $272.48 \mathrm{a}$ & $47.97 \mathrm{a}$ \\
\hline FM944GL & $896.31 \mathrm{a}$ & $404.49 \mathrm{a}$ & $45.13 \mathrm{~b}$ \\
\hline TMG42WS & $857.72 \mathrm{a}$ & $389.49 \mathrm{a}$ & $45.41 \mathrm{~b}$ \\
\hline TMG43WS & $782.59 \mathrm{a}$ & $344.50 \mathrm{a}$ & $44.02 \mathrm{~b}$ \\
\hline \multicolumn{4}{|l|}{ Thirds of the plant } \\
\hline Lower & $558.48 \mathrm{~b}$ & $239.33 \mathrm{c}$ & $42.85 \mathrm{a}$ \\
\hline Middle & $1,015.56 \mathrm{a}$ & $468.90 \mathrm{a}$ & $46.17 \mathrm{a}$ \\
\hline Upper & $754.42 \mathrm{~b}$ & $340.09 \mathrm{~b}$ & $45.08 \mathrm{a}$ \\
\hline \multicolumn{4}{|l|}{ Management system } \\
\hline With fungicide application & $912.16 \mathrm{a}$ & $408.45 \mathrm{a}$ & $44.78 \mathrm{a}$ \\
\hline Without fungicide application & $640.15 \mathrm{~b}$ & $297.03 \mathrm{~b}$ & $46.40 \mathrm{a}$ \\
\hline $\mathrm{CV}(\%)$ & 25.92 & 27.76 & 4.09 \\
\hline
\end{tabular}


Coutinho 2007). In this case, FM 944GL remained among the cultivars with the highest yield, even though it was more affected by the disease. However, the yield and quality of the fibers were affected by the $R$. areola fungus.

The cotton seed yield of the plots managed with fungicide increased up to $42.49 \%$, if compared to those without fungicide application. These results denote the importance of the chemical control and the destructive potential of the $R$. areola fungus, when this disease is not monitored or efficient control measures are not taken. These results confirm those found by Aquino et al (2008b) and Ascari et al. (2016), who assessed the effects of fungicide application to control the ramularia leaf spot and observed increases of $88 \%$ and $24.64 \%$ in the cotton seed yield, respectively.

Based on the results presented in this study, the ramularia leaf spot was related to the cotton crop yield, and the different levels of severity in the thirds of the plants may have contributed to the decrease of their leaf area. Therefore, the adoption of combined practices, such as the monitoring of diseases, use of less susceptible cultivars and control management with fungicides of different chemical groups are necessary.

\section{CONCLUSIONS}

1. The greater area under the disease progress curve of the ramularia leaf spot was found in the lower third of the cotton plants managed without fungicide application;

2. FM944GL and FM940GLT were the cultivars most affected by the Ramularia areola fungus;

3. The plants without fungicide application had the highest area under the disease progress curve and, consequently, a low leaf area;

4. According to the area under the disease progress curve found, the ramularia leaf spot affected the cotton yield.

\section{REFERENCES}

AQUINO, L. A. et al. Elaboração e validação de escala diagramática para quantificação da mancha de ramulária do algodoeiro. Summa Phytopathologica, v. 34, n. 4, p. 361-363, 2008a.

AQUINO, L. A. et al. Controle alternativo da mancha de ramulária do algodoeiro. Summa Phytopathologica, v. 34, n. 2, p. 131-136, 2008b.
ASCARI, J. P. et al. Severity of ramularia leaf spot and seed cotton yield in different sowing times. Revista Caatinga, v. 29, n. 3, p. 603-610, 2016.

BELTRÃO, N. E. M. et al. Ecofisiologia do algodoeiro (Gossypium hirsutum L. r. latifolium Hutch.). In: BELTRÃO, N. E. M.; OLIVEIRA, M. I. P. (Eds.). Ecofisiologia das culturas de algodão, amendoim, gergelim, mamona, pinhão-manso e sisal. Brasília, DF: Embrapa Informação Tecnológica, 2011. p. 65-124.

BERGAMIN FILHO, A. Curvas de progresso da doença. In: AMORIM, L.; REZENDE, J. A. M.; BERGAMIN FILHO, A. (Eds.). Manual de fitopatologia: princípios e conceitos. 4. ed. Piracicaba: Agronômica Ceres, 2011. p. 647-666.

CAMPBELL, C. L.; MADDEN, L. V. Introduction to plant disease epidemiology. New York: Wiley, 1990.

CHITARRA, L. G.; MEIRA, S. A.; MENEZES, V. L. Controle químico da mancha de ramulária do algodoeiro, causada por Ramularia areola, em função da idade da planta e da severidade da doença - safra 2003/2004. Brasília, DF: Embrapa Algodão, 2005. (Boletim de pesquisa e desenvolvimento, 58).

CIA, E. et al. Indicativo de variabilidade de Ramularia areola em algodoeiro no Brasil. In: CONGRESSO PAULISTA DE FITOPATOLOGIA, 33., 2011, Ituverava. Anais... Botucatu: Summa Phytopathologica, 2011. 1 CD-ROM.

CIA, E. et al. Reação de genótipos de algodoeiro à incidência de mancha de ramulária, no Estado de São Paulo. In: CONGRESSO BRASILEIRO DE ALGODÃO, 10., 2015, Foz do Iguaçu. Anais... Brasília, DF: Abrapa, 2015. p. 191.

CIA, E. et al. Reação de genótipos de algodoeiro à mancha de ramulária em diferentes épocas e ambientes. Summa Phytopathologica, v. 39, n. 3, p. 193-197, 2013.

COMPANHIA NACIONAL DE ABASTECIMENTO (Conab). Acompanhamento da safra brasileira de grãos: $9^{\circ}$ levantamento, safra 2015/16. Brasília, DF: Conab, 2016.

CURVELO, C. R. S.; RODRIGUES, P. G. B.; REZENDE, D. C. Microscopia eletrônica de varredura do processo infeccioso de Ramularia areola em folhas de algodoeiro. Tropical Plant Pathology, v. 35, n. 2, p. 108-113, 2010.

DIAS, L. D. E. et al. Controle de mancha de ramulária em algodão adensado. Revista Cultivar: Grandes Culturas, v. 1, n. 187, p. 8-11, 2015.

FREITAS, M. S. et al. Reação de cultivares de algodoeiro a Ramularia areola. In: CONGRESSO BRASILEIRO DE ALGODÃO, 10., 2015, Foz do Iguaçu. Anais.... Cuiabá: Abrapa, 2015. p. 189-190. 
FUZATTO, M. G.; CIA, E.; KONDO, J. I. Estabilidade fenotípica, um complemento relevante na avaliação e classificação de genótipos de algodoeiro para resistência a doenças. Summa Phytopathologica, v. 39, n. 2, p. 117 121, 2013.

FUZATTO, M. G.; CIA, E.; KONDO, J. I. Estabilidade fenotípica, um complemento relevante na avaliação e classificação de genótipos de algodoeiro para resistência a doenças. In: CONGRESSO BRASILEIRO DE ALGODÃO, 8., 2011, São Paulo. Anais.... Brasília, DF: Embrapa Algodão, 2011. p. 1382-1388.

GILIO, T. A. S. Divergência genética em genótipos de algodoeiro e quantificação de danos causados pela mancha de ramulária. 2014. 64 f. Dissertação (Mestrado em Genética e Melhoramento de Plantas) - Faculdade de Ciências Biológicas, Agrárias e da Saúde, Universidade do Estado de Mato Grosso, Tangará da Serra, 2014.

GIROTTO, L. et al. Identification of phenotypic and genotypic variability among the isolates of Ramularia areola of Brazilian cotton. American Journal of Plant Sciences, v. 4, n. 9, p. 1893-1898, 2013.

GONÇALVES, N. P. et al. Avaliação de genótipos de algodoeiro (Gossypium hirsutum L.) no norte de Minas Gerais. Revista de Biologia e Ciências da Terra, v. 10, n. 2, p. 59-66, 2010.

GRIMES, D. W.; CARTER, L. M. A linear rule for direct nondestructive leaf area measurements. American Society of Agronomy, v. 61, n. 3, p. 477-479, 1969.

JOHNSON, I. et al. Epidemiology of grey mildew and Alternaria blight of cotton. Archives of Phytopathology and Plant Protection, v. 46, n. 18, p. 2216-2223, 2013.

JULIATTI, F. C.; POLIZEL, A. C. Manejo integrado de doenças na cotonicultura brasileira. Uberlândia: Edufu, 2003.

MEHTA, Y. R.; MENTEN, J. O. Doenças e seu controle. In: FUNDO DE APOIO À CULTURA DO ALGODÃO (Facual). Algodão: pesquisas e resultados para o campo. Cuiabá: Facual, 2006. p. 156-205.

NKALUBO, S.; MELIS, R.; ÓPIO, F. Yield loss associated with anthracnose disease on Ugandan market-class dry bean cultivars. In: AFRICAN CROP SCIENCE SOCIETY CONFERENCE, 8., 2007, El-Minia. Proceedings... Kampala: ACSS, 2007. p. 869-874.
NOVAES, T. G. et al. Herança de resistência do algodoeiro a Ramularia areola. Summa Phytopathologica, v. 37, n. 2, p. 150-152, 2011.

OLIVEIRA, M. I. P. et al. Comportamento estomático em plantas mamoneira e algodoeiro sob deficiência hídrica em diferentes temperaturas. In: CONGRESSO BRASILEIRO DE MAMONA; SIMPÓSIO INTERNACIONAL DE OLEAGINOSAS ENERGÉTICAS, 1., 2010, João Pessoa. Anais... Brasília, DF: Embrapa Algodão, 2010. p. 12241229.

PEZENTI, L. F. et al. Phenotypic variability among isolates of Ramularia areola from Brazilian cotton. Tropical Plant Pathology, v. 38, n. 4, p. 329-321, 2013.

PIZZATO, J. A. et al. Epidemiologic study of Ramularia areola under different soil covers and spacings, for cotton crops. American Journal of Plant Sciences, v. 4, n. 11, p. 2049-2059, 2013.

PIZZATO, J. A. et al. Geostatistics as a methodology for studying the spatiotemporal dynamics of Ramularia areola in cotton crops. American Journal of Plant Sciences, v. 5, n. 9, p. 2472-2479, 2014.

RATHAIAH, Y. Spore germination and mode of cotton infection by Ramularia areola. Phytopathology, v. 67, n. 1, p. 351-357, 1977.

SHIVANKAR, S. K.; WANGIKAR, P. D. Estimation of crop losses due to grey mildew disease of cotton caused by Ramularia areola. Indian Phytopathology, v. 45, n. 1, p. 71-73, 1992.

SUASSUNA, N. D.; COUTINHO, W. M. Manejo das principais doenças do algodoeiro no Cerrado brasileiro. In: FREIRE, E. C. Algodão no Cerrado do Brasil. Brasília, DF: Abrapa, 2007.

SUASSUNA, N. D.; COUTINHO, W. M. Manejo de doenças. In: BORÉM, A.; FREIRE, E. C. (Eds.). Algodão: do plantio à colheita. Viçosa: UFV, 2014. p. 250-270.

SUASSUNA, N. D.; COUTINHO, W. M.; FERREIRA, A. C. B. Manejo da mancha de ramulária em algodoeiro. Brasília, DF: Embrapa Algodão, 2006a. (Comunicado técnico, 272).

SUASSUNA, N. D.; COUTINHO, W. M.; MORELLO, C. L. Resistência genética de algodoeiro à mancha de ramulária. Brasília, DF: Embrapa Algodão, 2006b. 